\title{
Characterization of Two Cucurbitaceae Species Seeds Flour and its Utilization in Biscuits Processing
}

\author{
Abdeen Elsiddig Eltyeb Elkhedir ${ }^{1 *}$ and Abel Moneim Ebrahim Mustafa ${ }^{2}$ \\ ${ }^{1}$ Industrial Research and Consultancy Center (IRCC), Khartoum, Sudan \\ Department of Food Science and Technology, Faculty of Agriculture, Khartoum University-Khartoum, Sudan
}

\begin{abstract}
The objectives of this study were to characterize and utilize the seeds flour of two species of cucurbitaceae with wheat flour for biscuits making. Cucurbitaceae species used were (Tibish) Cucumis melo agrestis and (Fagoos) Cucumis metuliferus obtained from Khartoum and Darfor, respectively, season 2011/12. The cucurbitaceae seeds were milled into flour by warring blender then proximate analysis, minerals composition and protein fractions were conducted. Biscuits were made from cucurbitaceae seeds flour and wheat flour in ratios 5:95, 10:90 and 15:85 respectively. Organolyptic quality of biscuits was investigated. Proximate analysis of the seeds flour revealed that the crude protein was 26.1 and $27.0 \%$ respectively, crude fat was 26 and $33.3 \%$, crude fiber 24.8 and $25 \%$, ash 2.8 and 5.3 respectively. The results proved that the two species contained height amount of minerals especially iron $(7.4 \mathrm{mg} / 100 \mathrm{~g}$ and $5.7 \mathrm{mg} / 100)$. Protein fractions showed that the water- and salt-soluble proteins (albumin and globulin) of the two species of cucurbitaceae seeds flour were the ranges of $(32.4,35.1)$ and 26.57 to $28.7 \%$ respectively, prolamin and glutelin fractions were $(10.9,11.15)$ and $(23.85,19.7 \%)$, respectively. The highest spread ratio of the wheat biscuits and composite cucurbitaceae seeds flour biscuits was observed in 5\%Fagoos (3.63) and the lowest in 15\% Tibish (4.07). The mean quality scores for the overall acceptability was highest in 15\%Tibish (7.87) and the lowest score of (4.5) was obtained by $5 \%$ Fagoos. In conclusion the results revealed that the good nutritional value of seeds flour reinforced the usefulness of cucurbitaceae seeds flour in biscuits making.
\end{abstract}

Keywords: Cucurbitaceae; Tibish; Fagoos; Biscuits; C. metuliferus; C. melo agrestis

\section{Introduction}

The cucurbitaceae is a predominantly tropical plant family of about 130 extant genera and 900 species, the over-whelming majority of which are distributed in Africa, Madagascar, Central and South America and Southeast Asia [1]. In tropical Africa, cucurbitaceae distributions especially characteristic of the drier regions [2], the cucurbitaceae are an important source of vegetables, fruits, edible seeds and seed oil, domestic utensils, medicines, water, animal fodder and fuel. In spite of this potential, less than $0.5 \%$ of the species are being commercially exploited and the family is relatively poorly known.

Good nutrition is a basic human right. In order to have a healthy population that can promote development, the relation between food, nutrition and health should be reinforced. In developing countries, one of the ways of achieving this is through the exploitation of available local resources, in order to satisfy the needs of the increasing population.

Knowledge of the nutritive value of local dishes, soup ingredients and local foodstuffs is necessary in order to encourage the increased cultivation and consumption of those that are highly nutritive. This consumption will help to supplement the nutrients of the staple carbohydrate foods of the poor who cannot afford enough protein foods of animal origin. Cereals are staple foods for human nutrition and their incorporation into various products is of great economic importance [3].

The fruits from Cucurbitaceae species are valued for nutritional and medicinal purposes [4]. The remaining portion of the Cucurbit fruits, especially the seed (often discarded as a waste), can be utilized for other food applications, oil extraction and animal feeds contributing to less waste disposal and value-addition. The high protein of the seed kernels in some of cucurbitaceae family coupled with a fairly high concentration and distribution of the amino acids; make it suitable for fortification of foods [5].
The uses of cucurbitaceae seeds as potential sources of oil have been reported by Jacks et al. [6]. The high content of oil, showing useful characteristics such as odorlessness, and good color and appearance, make these seeds suitable for oil industrial applications [7]. High protein levels in cucurbitaceae seeds have also been shown by other researchers from various countries, such as Lal et al. [8] who studied the kernel oils of 15 species of cucurbitaceae seeds from India and showed that the oil- free kernel meals of different species had 60 to $70 \%$ of proteins. Jacks [6] reviewed the usefulness of cucurbitaceae seeds and showed that globulins account for 70 to $90 \%$ of protein, they are rich in arginine, aspartic and glutamic acids.

The use of wheat as an ample food due to the properties of proteins in flour which accelerate rheological properties of dough related to baking quality. However, wheat contains less amount of protein and also deficient in certain amino acids cause malnutrition. For this reason, most developing countries were interested in the possibility of replacing the wheat needed for making baked goods, wholly or partly with flour obtained from home grown products. Possible sources are cassava, yam, maize, millet, soy, peanut, cucurbitaceae seeds and sorghum [9-15].

Since the objectives of this study were to investigate the characterization and Utilization of two species of cucurbitaceae seeds flour in biscuits processing.

${ }^{*}$ Corresonding author: Abdeen Elsiddig Eltyeb Elkhedir, Industrial Research and Consultancy Center (IRCC), Khartoum, Sudan, E-mail: abdeensiddig@yahoo.com

Received January 20, 2015; Accepted March 19, 2015; Published March 26 2015

Citation: Elkhedir AEE, Mustafa AME (2015) Characterization of Two Cucurbitaceae Species Seeds Flour and its Utilization in Biscuits Processing. $J$ Food Process Technol 6: 442. doi:10.4172/2157-7110.1000442

Copyright: (C) 2015 Elkhedir AEE, et al. This is an open-access article distributed under the terms of the Creative Commons Attribution License, which permits unrestricted use, distribution, and reproduction in any medium, provided the original author and source are credited. 
Citation: Elkhedir AEE, Mustafa AME (2015) Characterization of Two Cucurbitaceae Species Seeds Flour and its Utilization in Biscuits Processing. J Food Process Technol 6: 442. doi:10.4172/2157-7110.1000442

\section{Materials and Methods}

\section{Materials}

The seeds of two species of cucurbitaceae family namely Tibish, and Fagoos were obtained from Sudan regions of Khartoum and Darfor, season 2011/12.

Seeds were separated manually from fruits, and fibrous material was washed with tap water. The seeds were dried in an oven at $40^{\circ} \mathrm{C}$. The dried seeds were ground into powder by using porcelain mortar and pestel. The powder was thoroughly mixed, stored at deep freezer, and used as the stock seed samples for further analyses. Wheat flour was obtained from flour mill in Khartoum North. Sugar powder, oil, sodium chloride, ammonium bicarbonate and shortenings were purchased from the local market.

\section{Methods}

Proximate analysis of cucurbitaceae seeds was carried out according to the method described by AOAC [15]. Minerals were determined by the Atomic Absorption Spectrophotometer (A.A.S model GBC 932 plus) according to AOAC methods [15].

Protein fractions: the nitrogen from the defatted flour was extracted stepwise by a series of solvents according to the Osborne technique [16].

Preparation of cucurbitaceae seeds flours the seeds were milled using lab mill. The flour was sieved by 60 mesh-sieves.

Composite flours of wheat and cucurbitaceae seeds flours were prepared by different replacement levels $(5,10$, and 15\%) of cucurbitaceae seeds flour.

Biscuits were prepared from composite flours of wheat and cucurbitaceae seeds flour and its physical evaluation according to the methods described by Manohar and Rao [17].

\section{Sensory evaluation of biscuits}

Were performed by panelist using scoring method including appearance and color (pale yellow to dark brown), texture (friability), odor (fruity, caramel, rancid), and taste (salty, sweet, bitter and sour, they were rated on an anchored line scale that provided a 0-9 score range $(0=$ minimum; $9=$ maximum, the test was carried out by 10 panelists according to the method described by Larmond [18].

\section{Statistical analysis}

Results expressed as the mean value \pm standard deviation (SD) were performed using Duncan multiple range test (DMRT) according to the procedures described by Gomez and Gomez [19]. Data were assigned in a Completely Randomized Design (CRD). Software of the Statistical Analysis Systems (SAS, 2004) was used to analyze data.

\section{Results and Discussion}

\section{Chemical composition of cucurbitaceae seeds flour}

Table 1 shows the results of the chemical composition of the two species of cucurbita seeds flour (Tibish and Fagoos).

\section{Protein content}

According to the results in Table 1 protein content of seeds flour of the two species Tibish and Fagoos were 27.27 and $27.78 \%$ respectively. The results were above of the finding of Mariod et al., [20] who concluded that the protein content of seeds of tibish and fagoos were $16.6 \%$ and $14.5 \%$, respectively. Statistical analysis revealed significant differences between the two tested samples.

\section{Oil content}

A according to Table 1, oil of the two species of cucurbita seeds flour (Tibish and Fagoos) were $27.17 \%$ and $34.25 \%$ respectively, the highest oil content was obtained by Fagoos. The value of oil content obtained from Tibish was above than the value reported by Mariod et al., [20] who reported the oil content of Tibish was $23.33 \%$.

\section{Crude fiber}

As shown in Table 1 the two species (cucurbita seeds flour) Tibish and Fagoos has 26.12 and $25.51 \%$ crude fiber, respectively. Values obtained for species were within the range of 13.34-34.36\% reported by Mariod et al. [20]. Statistical analysis indicated crude fiber obtained for Tibish and Fagoos was no significantly different.

\section{Ash content}

The ash content of the Tibish and Fagoos seeds flour was 5.53 and $4.73 \%$ respectively, value obtained for Tibish was in agreement with the result obtained by Mariod et al. [20] who stated that the ash content of Tibish was $5.2 \%$, and fagoos $8.3 \%$ which above with our finding.

\begin{tabular}{|l|c|c|c|c|}
\hline \multirow{2}{*}{ Cucurbita seeds flour } & \multicolumn{3}{|c|}{ Parameters } \\
\cline { 2 - 5 } & Oil content $\%$ & Protein $\%$ & Fiber\% & Avh\% \\
Carbohydrates $\%$ & & $5.53^{\mathrm{a}} \pm 0.0$ \\
\hline Tibish & $27.17^{\mathrm{b}} \pm 0.07$ & $27.27^{\mathrm{b}} \pm 0.14$ & $26.12^{\mathrm{a}} \pm 0.14$ & $4.73^{\mathrm{a}} \pm 0.14$ \\
\hline Fagoos & $34.25^{\mathrm{a}} \pm 0.14$ & $27.78^{\mathrm{a}} \pm 0.14$ & $25.51^{\mathrm{a}} \pm 0.42$ & $8.23^{\mathrm{a}} \pm 0.21$ \\
\hline L.s.d 0.05 & 0.5357 & 0.4639 & 0.4309 & 0.2718 \\
\hline
\end{tabular}

Each value in the table is a mean of 3 replications

Mean \pm SD value(s) bearing different superscript letter(s) within the same column differ significantly $(P \leq 0.05)$

Table 1: Proximate analysis of the two species of cucurbitaceae seeds flour.

\begin{tabular}{|c|c|c|c|c|c|c|c|}
\hline \multirow{2}{*}{$\begin{array}{l}\text { Cucurbitaceae } \\
\text { Samples }\end{array}$} & \multicolumn{7}{|c|}{ Minerals } \\
\hline & $\mathrm{Ca}$ & Mg & $\mathrm{Na}$ & $\mathbf{K}$ & Mn & $\mathrm{Cu}$ & $\mathrm{Fe}$ \\
\hline Tibish & $10.1^{b}$ & $45.1^{b}$ & $44.1^{\mathrm{b}}$ & $158.9^{b}$ & $1.13^{b}$ & $2.33^{b}$ & $7.4^{\mathrm{b}}$ \\
\hline Fagoos & $19.7^{d}$ & $56.8^{d}$ & $23.6^{d}$ & $194.7^{d}$ & $0.98^{d}$ & $2.2^{\mathrm{b}}$ & $5.7^{d}$ \\
\hline L.S.D 0.05 & 0.4578 & 0.0999 & 0.4578 & 0.6551 & 0.0153 & 0.2997 & 0.2079 \\
\hline
\end{tabular}

Each value in the table is a mean of 3 replications

Mean value (s) bearing different superscript letter(s) within the same column differ significantly $(P \leq 0.05)$

Table 2: Minerals content of the two species of cucurbitaceae seeds flour (mg/100 g). 
Citation: Elkhedir AEE, Mustafa AME (2015) Characterization of Two Cucurbitaceae Species Seeds Flour and its Utilization in Biscuits Processing. J Food Process Technol 6: 442. doi:10.4172/2157-7110.1000442

Page 3 of 4

\begin{tabular}{|l|c|c|c|c|c|}
\hline $\begin{array}{l}\text { Cuccrbita } \\
\text { Seeds flour }\end{array}$ & Albumin\% & Globulins\% & Prolamin\% & Glutelin\% & $\begin{array}{c}\text { Insoluble protein\% } \\
\text { (residues) }\end{array}$ \\
\hline Tibish & $32.4^{\mathrm{b}} \pm 0.14$ & $26.57^{\mathrm{b}} \pm 0.21$ & $9.6^{\mathrm{a}} \pm 0.15$ & $23.85^{\mathrm{a}} \pm 0.49$ & $8.01^{\mathrm{a}} \pm 0.15$ \\
\hline Fagoos & $35.1^{\mathrm{a}} \pm 0.42$ & $28.7^{\mathrm{a}} \pm 0.24$ & $10.9^{\mathrm{a}} \pm 0.49$ & $19.7^{\mathrm{b}} \pm 0.42$ & $8.9^{\mathrm{a}} \pm 0.42$ \\
\hline L.s.d \#0.05 & 1.270 & 1.9059 & 3.303 & 0.635 & $101.72^{\mathrm{a}} \pm 0.56$ \\
\hline
\end{tabular}

Each value in the table is a mean of 3 replications

Mean value (s) bearing different superscript letter(s) within the same column differ significantly $(P \leq 0.05)$

Table 3: Protein fractions of the two species of cucurbitaceae seeds flour.

\begin{tabular}{|l|c|c|c|c|}
\hline Biscuit samples & Width $\mathbf{( c m})$ & Thickness $\mathbf{( c m )}$ & Spread ratio & Spread factor \\
\hline Wheat & 5.5 & 1.42 & $3.87^{\mathrm{b}}$ & $100^{\mathrm{g}}$ \\
\hline $\mathbf{5 \%}$ Tibish & 5.41 & 1.47 & $3.68^{\mathrm{b}}$ & $95.1^{\mathrm{i}}$ \\
\hline $10 \%$ Tibish & 5.45 & 1.49 & $3.66^{\mathrm{j}}$ & $94.6^{\mathrm{j}}$ \\
\hline $15 \%$ Tibish & 5.48 & 1.51 & 3.63 & $93.8^{\mathrm{k}}$ \\
\hline $\mathbf{5 \%}$ Fagoos & 5.3 & 1.3 & $4.07^{\mathrm{a}}$ & $105.2^{\mathrm{b}}$ \\
\hline $10 \%$ Fagoos & 5.34 & 1.32 & $4.05^{\mathrm{a}}$ & $104.6^{\mathrm{d}}$ \\
\hline $15 \%$ Fagoos & 5.25 & 1.3 & $4.04^{\mathrm{a}}$ & $104.2^{\mathrm{c}}$ \\
\hline L.s.d 0.05 & - & - & 0.129 & 0.152 \\
\hline
\end{tabular}

Each value in the table is a mean of 3 replications

Mean \pm SD value(s) bearing different superscript letter(s) within the same column differ significantly $(P \leq 0.05)$

Table 4: Physical characteristics of wheat flour and composite cucurbitaceae seeds flour biscuits.

\section{Available carbohydrates (CHO)}

As shown in Table 1, Tibish and Fagoos seeds flour has 13.9 and $8.23 \%$ carbohydrates, respectively, the value obtained for Tibish was in agreement with the result obtained by Mariod et al. [20].

\section{Minerals content of cucurbitaceae seeds flour}

Table 2 shows minerals content of the two species (cucurbita seeds flour). Iron content was $1.2 \mathrm{mg} / 100 \mathrm{~g}$ (Fagoos) and $7.4 \mathrm{mg} / 100$ g (Tibish), the high content of iron would serve to complete the deficiency of iron in wheat. Although the two species contained moderate concentrations of minerals, the Fagoos and Tibish were good sources of some minerals.

\section{Protein fractions of seeds flour of the two species of cucurbitaceae}

Table 3 shows the water- and salt-soluble proteins (albumin and globulin), Prolamin, glutelin and Insoluble protein residue of the two species (Tibish and Fagoos) of cucurbitaceae seeds flour. The result obtained for albumin and glubulin were near to that results obtained by Giami [21], who reported the albumin and globulin to constitute about $59 \%$ of the total proteins of the pumpkin seed.

The albumin and globulin protein fractions have been reported to have higher levels of the amino acid lysine [22].

The albumin and globulin protein fractions of the two species of cucurbitaceae seeds flour comprised about 56.9-68.8\%. Thus, the nutritional value of biscuits made from composite flour of cucurbitaceae seeds flour and wheat flour is expected to increase.

\section{Physical evaluation of biscuits}

The mean values of physical characteristics of wheat biscuits and composite cucurbitaceae seeds flour biscuits are presented in Table 4. The data recorded for spread ratio was ranging from 3.63 to 4.07 . Considering the spread factor of control biscuits (100\% wheat flour as 100), results given in Table 5) indicated that the higher value was 105.2 obtained by 5\% Fagoos and the lower spread factor was 93.8 obtained

\begin{tabular}{|l|c|c|c|c|c|}
\hline \multirow{2}{*}{ Treatment } & \multicolumn{5}{|c|}{ Characteristics } \\
\cline { 2 - 6 } & Color & Taste & Odor & Texture & Over all acceptability \\
\hline $5 \%$ Tibish & $7.4^{\mathrm{e}}$ & $7.3^{\mathrm{b}}$ & $6.45^{\mathrm{f}}$ & $7.37^{\mathrm{b}}$ & $7.16^{\mathrm{d}}$ \\
\hline $10 \%$ Tibish & $7.6^{\mathrm{c}}$ & $8.1^{\mathrm{a}}$ & $7.8^{\mathrm{b}}$ & $6.8^{\mathrm{d}}$ & $7.58^{\mathrm{b}}$ \\
\hline $15 \%$ Tibish & $8^{\mathrm{b}}$ & $6.9^{\mathrm{c}}$ & $8.1^{\mathrm{a}}$ & $8.1^{\mathrm{a}}$ & $7.87^{\mathrm{a}}$ \\
\hline $5 \%$ Fagoos & $5.62^{\mathrm{f}}$ & $7^{\mathrm{c}}$ & $6.8^{\mathrm{d}}$ & $4.5^{\mathrm{f}}$ & $5.94^{\mathrm{g}}$ \\
\hline $10 \%$ Fagoos & $8^{\mathrm{b}}$ & $6.5^{\mathrm{d}}$ & $6.3^{\mathrm{e}}$ & $7.2^{\mathrm{c}}$ & $7.04^{\mathrm{f}}$ \\
\hline $15 \%$ Fagoos & $7.5^{\mathrm{d}}$ & $7^{\mathrm{c}}$ & $6.7^{\mathrm{a}}$ & $7.2^{\mathrm{c}}$ & $7.27^{\mathrm{c}}$ \\
\hline Wheat & $8.3^{\mathrm{a}}$ & $6.8^{\mathrm{c}}$ & $7.3^{\mathrm{c}}$ & $6.58^{\mathrm{e}}$ & $7.12^{\mathrm{e}}$ \\
\hline Lsd ${ }_{0.05}$ & 0.058 & 0.216 & 0.058 & 0.076 & 0.015 \\
\hline
\end{tabular}

Each value in the table is a mean of 3 replications

Mean \pm SD value(s) bearing different superscript letter(s) within the same column differ significantly $(P \leq 0.05)$

Table 5: Sensory evaluation of composite flour of wheat and cucurbitaceae seeds flour biscuits.

by $15 \%$ Tibish. The data recorded a gradual decreasing of spread ratio of all biscuits with all the replacement of cucurbitaceae seeds flour.

\section{Sensory evaluation of the biscuits}

The biscuits were evaluated for color, taste, odor, texture and overall acceptability. The mean quality scores for the overall acceptability was highest in 15\% Tibish (7.87) and the lowest score of (4.5) was obtained by $5 \%$ Fagoos.

\section{Conclusions}

1. The results of the present study showed that cucurbitaceae seeds contained appreciable amounts of crude protein, crude fat, crude fiber and moderate amount of ash content.

2. The high amount of protein and minerals especially iron as well as amino acid lysine reinforced the usefulness of cucurbitaceae seeds flour for supplementation of wheat flour.

\section{References}

1. Jeffrey C (1980) Flora of tropical East Africa (Cucurbitaceae). Journal Bot Zhurn 90: 332-335.

2. Maggs GL, Guarino I (1995) Worked example: Mapping the ecogeographic distribution of biodiversity In: genetic Diversity, technical guidelines, international, Wallingford.

3. Pena R, Fokou E, Leke R, Fotso M, Souopgui J, et al. (2006) Methods of preparation and nutritional evaluation of dishes consumed in a malaria endemic zone in camerooon (Ngali II). Afr J Biotechnol 4: 273-278.

4. Bates DM, Robinson RW (1990) Appendix: An outline classification of the cucurbitaceae. Cornell University Press, Ithaca.

5. Alfawaz MA (2004) Chemical Composition and Oil Characteristics of Pumpkin (Cucurbita maxima) Seed Kernels), Food Sci and Agric 129: 5-18.

6. Jacks TJ, Henserling TP, Yatsu LY (1972) Cucurbit seeds. I. Characteristic and the uses of oils and proteins. A review Econ Bot 26: 135-141.

7. Al-Khalifa AS (1996) Physicochemical characteristics, fatty acid composition and lipoxygenase activity of crude pumpkin and melon seed oils. J Agric Food Chem 44: 964-966.

8. Lal BM, Datta N, Madaan TR (1983) A study of kernel oils of some cultivated cucurbits. Plant Food Hum Nutr 32: 83-85. 
Citation: Elkhedir AEE, Mustafa AME (2015) Characterization of Two Cucurbitaceae Species Seeds Flour and its Utilization in Biscuits Processing. J Food Process Technol 6: 442. doi:10.4172/2157-7110.1000442

Page 4 of 4

9. Jacks TJ (1986) Cucurbit Seed Protein and Oil. Plant Proteins: Applications, Biological Effects, and Chemistry.

10. Pasqualone A, Caponio F, Summo C, Paradiso VM, Bottega G, et al. (2010) Gluten-free bread making trials from cassava (Manihot esculenta Crantz) flour and sensory evaluation of the final product. International Journal of Food Properties 13: 562-573.

11. Akinrele IA (1970) Fermentation studies on maize during the preparation of a traditional african starch? cake food. Journal of the Science of Food and Agriculture 21: 619-625.

12. Romney DL, Thorne P, Lukuyu B, Thornton PK (2003) Maize as food and feed in intensive smallholder systems: management options for improved integration in mixed farming systems of east and southern Africa. Field crops research 84 159-168.

13. Dicko MH, Gruppen H, Traoré, AS, Voragen AG, Van Berkel WJ (2006) Review: sorghum grain as human food in Africa: relevance of starch conten and amylase activities. African journal of biotechnology 5: 384-395.

14. Akinrele IA, Edwards CC (1971) An assessment of the nutritive value of a maize-soya mixture,'Soy-Ogi', as a weaning food in Nigeria. Br J Nutr 26: 177185
15. Sidney W (2000) Official methods of analysis. Association of Official Analytical Chemists, Washington.

16. Osborne TB (1924) The vegetables proteins. Loongmans, Green, New York

17. Manohar RS, Rao PH (1997) Effect of mixing period and additives on the rheological characteristics of dough and quality of biscuit. Cereal Sci 25: 197 206.

18. Larmond E (1977) Laboratory Methods for Sensory Evaluation of Food Canadian Government Publishing Center, Ottawa, Canada.

19. Gomez KA, Gomez AH (1984) Statistical Procedures for Agricultural Research. John Wiley and Sons Inc., New York, USA.

20. Mariod AA, Ahmed YM, Khaleel G, Siddig A, Gabra AM, et al. (2009) A comparative study of the properties of six Sudanese cucurbit seeds and seed oils. J Am Oil Chem Soc 86: 1181-1188.

21. Giami SY (2004) Effect of fermentation on the seed proteins, Nitrogenous constituents, antinutrients and nutritional quality of fluted pumpkin (Telfairia occidentalis Hook). Food Chem 88: 397-404.

22. Johnson VA, Lay CL (1974) Genetic improvement of plant protein. Journal of Agricultural and Food Chemistry 22: 558-566. 